http://jmscr.igmpublication.org/home/ ISSN (e)-2347-176x ISSN (p) 2455-0450

crossref DOI: https://dx.doi.org/10.18535/jmscr/v9i3.15

\author{
D) Journal Of Medical Science And Clinical Research

\title{
A Case of Ruptured Interstitial Ectopic Pregnancy
}

\author{
Authors \\ Dr Nitu Bharti ${ }^{1}$, Dr Soma Bandhopadhyay ${ }^{2}$, Dr Rafia Gul ${ }^{3}$ \\ ${ }^{1} 2^{\text {nd }}$ year PGT, Department of Obstetric s and Gynaecology, KMCH, Katihar \\ ${ }^{2} \mathrm{Head}$ of Department (Obstertrics and Gynaecology), KMCH, Katihar \\ ${ }^{3} 2^{\text {nd }}$ year PGT, Department of Obstetrics and Gynaecology, KMCH, Katihar
}

\section{Introduction}

Ectopic pregnancy is one in which the fertilized ovum is implanted and develops outside the normal endometrial cavity. Interstitial ectopic pregnancy is located outside the uterine cavity in the part of the fallopian tube that penetrates the muscular layers of the uterus. It is also known as cornual ectopic pregnancy. It is a rare type of ectopic pregnancy which accounts $2-4 \%$ of all the ectopic pregnancy. It's mortality rate is 6-7 times higher than other types of ectopic pregnancies.

The risk factors includes assisted reproductive techniques, previous tubal pregnancy, tubal surgeries, a history of pelvic inflammatory disease and sexually transmitted diseases. Early diagnosis is made by USG and B HCG level.

\section{Aim}

To present a case of left sided ruptured interstitial ectopic pregnancy

\section{Setting}

Department of Obstetrics and Gynecology, Katihar Medical College, Katihar

\section{Case Summary}

A 35 year old G4P2+1L2 with 2 months amenorrhea presented to obstetrics causality with complaints of acute pain abdomen since 4 days. Pain was all over the abdomen with no aggravating or relieving factors. She also had complained of spotting per vaginum since 4 days. There was history of nausea and vomiting (3-4 episodes) since 2 days. Patient also had a history of syncopal attack 1 day back lasting for 1 -2 minutes. Bladder and bowel were regular. Her previous menstrual cycle was normal. There was no significant past, personal, or any surgical history.

\section{On Examination}

Patient was conscious, co-operative, well oriented with time, place and person.

Blood pressure - 90/60 mmHg

Pulse rate- 130 beats per minute

Afebrile

Pallor +++

No icterus, cyanosis, clubbing, lymphadenopathy, edema

Per Abdomen- distension +, tenderness +

Per Speculum- spotting +

Per vaginum- uterus anteverted, bulky, left fornix full, cervical motion tenderness + 


\section{Investigation}

Hb- 3.4 gm \%,Platelet count- 2.3/cmm, Blood group- B positive, RBS- $134 \mathrm{gm} / \mathrm{dl}$, Total leukocyte count- $8200 / \mathrm{cmm}$, Blood urea- 65.2 $\mathrm{mg} / \mathrm{dl}$, serum creatinine $-1.36 \mathrm{mg} / \mathrm{dl}$, SGOT23IU/L, SGPT- 18 IU/L, ALP- 78 IU/L, Serum bilirubin- $0.6 \mathrm{mg} / \mathrm{dl}$, Serum uric acid -5.95 ,Serum calcium - 7.75, Serum protein - 6.98, Serum Albumin- 3.64,Serum globulin -3.34, A/G ratio1.0, $\mathrm{HIV}$ - non reactive, $\mathrm{Hbs} \mathrm{Ag}$ - non reactive, Anti $\mathrm{HCV}$ - non reactive

USG- Left sided tubo-ovarian mass size$51 \times 49 \times 48 \mathrm{~mm}$

Suggestive of ruptured ectopic pregnancy, mild haemoperitoneum

\section{Ope rative Procedure}

After all preliminary investigation patient was taken for emergency laparotomy in view of ruptured left sided interstitial ectopic pregnancy. Under general anesthesia with aseptic precautions abdomen was opened in layers. Abdomen cavity was filled with blood. Blood

was suctioned out and rupture site was identified as left Interstitial. In view of massive and uncontrolled bleeding subtotal hysterectomy was done.

\section{Post Operative Peroid}

She was given injectable antibiotics. Post operative period was uneventful and patient was discharged on $8^{\text {th }}$ post operative day and to be followed on OPD basis.

\section{Discussion}

Earlier patient presentation and precise diagnostic technology typically allow identification before rupture .In these cases symptoms and signs of ectopic pregnancy are present. Classical triad of amenorrhea, bleeding or spotting per vaginum and abdomen pain is present. In rupture lower abdominal pain and pelvic pain is usually severe. Abdominal palpation elicits distension and tenderness.

\section{Conclusion}

After thorough review of history, examination and investigation exploratory laparotomy was done and since the site of ruptured ectopic was identified to be in the left cornua or interstitium with non viable intrauterine pregnancy, a quick subtotal hysterectomy was done with proper post operative care and blood transfusion. Patient was discharged on $8^{\text {th }}$ post operative day.

So, timely intervention can significantly decrease morbidity and mortality in case of ruptured ectopic.

\section{Bibliography}

1. Barrel, J.S., \& Novak,E.(2020). Berek and Novak's gyanecology. chapter $32 .\left(16^{\text {th }}\right.$ ed.). Philadelphia; Lippincott Williams \& Williams.

2. Cunningham, F.G., Leveno, K.J., etal, editors. Williams obstetrics chapter $19\left(25^{\text {th }}\right.$ ed.). Newyork McGraw-hill Education; 2018:pg- 380-381

3. Tulane T, Al- Jaroudi D. Interstitial Pregnancy: results generated from the society of Reproductive Surgeons registry. Obstet Gynecol 2004;103:47-50. 